terminy ,ziemie ruskie Korony”, ,szkoła parafialna” i finalnie pozostawia niedosyt czytelnikowi, który po lekturze nadal nie ma pewności czy pojawienie się na konkretnym terenie szkół zakonnych powodowało słabnięcie szkót parafialnych, czy też słabnięcie szkót parafialnych powodowało konieczność zakładania nowych szkół zakonnych. Być może jest to rzeczywiście problem nie do rozwiązania z racji niedostatku źródeł. Nie tłumaczy to jednak wykorzystywanie w tego typu publikacji przez Jacka Chachaja podręczników akademickich do nauczania historii wychowania (S. Kot, S. Litak).

$\mathrm{Z}$ całą pewnością publikacja warta jest lektury i poznania. Bo po pierwsze, jej istnienie przyczyni się do spopularyzowania wiedzy o polskich zakonach nauczających, do których najczęściej zalicza się jedynie jezuitów. Po wtóre zaś, doświadczenia pijarskie w zakresie nauczania być może wzbogacą współczesną edukację historyczną, gdzie nadal brakuje odpowiedzialności za młode pokolenia, które nie znają właściwego znaczenia takich pojęć jak: patriotyzm, obywatelskość i Ojczyzna.

Edyta Głowacka-Sobiech

\title{
Bogusław Śliwerski, Przyrzeczenie Harcerskie. Historia. Metody- ka. Manipulacje, Wydawnictwo Impuls, Kraków 2009, ss. 244
}

Zbliżająca się rocznica stulecia istnienia harcerstwa na ziemiach polskich jest doskonałą okazją, by przypomnieć, nie tylko samym harcerzom, czym ów ruch był w przeszłości dla Polaków, jakie funkcje społeczne spełniał, jakie ideały mu przyświecały, na czym polegała istota harcerskiej przygody.

Książką, która z pewnością przybliży czytelnikowi te i wiele innych kwestii związanych z harcerską służbą jest praca Bogusława Śliwerskiego zatytułowana: Przyrzeczenie Harcerskie. Historia. Metodyka. Manipulacje, wydana przez Wydawnictwo Impuls w 2009 r. Tematyka prezentowanej publikacji koncentruje się wokół tekstu harcerskiego przyrzeczenia, a ponieważ jest ono esencją ruchu, książka ta jest po prostu o harcerstwie.

Autorowi przyświecała bardzo szlachetna idea przy pisaniu tej książki. Założył bowiem we „Wstępie”, że każdy instruktor, by zrozumieć cechy i funkcje harcerskiego przyrzeczenia, powinien przede wszystkim poznać jego dzieje, by pogłębić swojá świadomość historyczna z korzyścia dla petnienia harcerskiej służby. B. Śliwerski przypomina także spór instruktorski z lat 1980-1981, który wywołany był co prawda sytuacją polityczną, ale przy okazji ukazał z całą bezwzględnością nieznajomość dziejów harcerskich wśród kadry. Poza tym, co szczególnie było gorącym tematem wśród harcerzy po 1989 r., to spory o rodowód harcerstwa, o prawo do używania harcerskich symboli, a także o to, kto tak w rzeczywistości jest prawdziwym harcerzem. B. Śliwerski przy rozwiązywaniu tego typu sporów poleca sięganie do przeszłości i właśnie w niej szukanie nie tylko skautowej tożsamości, ale i odpowiedzi na liczne pytania. Jego intencje nabierają większej wiarygodności, gdy dowiadujemy się, że prezentowana publikacja pisana była przed 1989 r., $w$ okresie restrykcyjnej cenzury i totalitarnych ograniczeń. 
Autor nie poprzestaje jedynie na chronologicznym przedstawieniu historii roty przyrzeczenia harcerskiego, ale także stara się odpowiedzieć na następujące pytania: Skąd została zaczerpnięta pierwsza formuła przyrzeczenia harcerskiego?, Ile było redakcji jego pierwowzoru?, Kiedy, przez kogo i z jakimi oczekiwaniami został tekst zatwierdzony i wprowadzony w życie?, Z jakiego powodu zmieniano tekst roty?, Dlaczego w dziejach harcerstwa nie mogła obowiązywać jedna formuła przyrzeczenia harcerskiego?

Praca składa się z pięciu rozdziałów, a całą pracą rządzi porządek chronologiczny. Zatem pierwszy z nich sięga do korzeni ruchu i opisuje angielskie pierwowzory przyrzeczeń. W kolejnej części pracy Autor przedstawił genezę i ewolucję przyrzeczenia polskich skautów w latach jeszcze niewoli narodowej i pierwszej wojny światowej (1909-1918). Rozdział trzeci natomiast dotyczy istoty harcerskich przyrzeczeń w okresie II Rzeczypospolitej, kiedy zaczął pojawiać się wielogłos w ruchu (np. poprzez istnienie Czerwonego Harcerstwa). O przyrzeczeniu i harcerstwie lat wojny i okupacji traktuje rozdział czwarty. W ostatnim natomiast autor opisał ewolucję i istotę harcerskich przyrzeczeń w okresie 1944 - 1981. Ta część pracy jest najobszerniejsza, gdyż właśnie ten okres w dziejach harcerstwa był najdramatyczniejszy. Uzupełnieniem pracy jest aneks, który zestawia roty przyrzeczenia harcerskiego, w tym także tłumaczenia wersji przyrzeczenia skautów angielskich.

Książka jest bardzo staranie przygotowana także pod względem edytorskim. Znajduje się w niej wiele ciekawych ilustracji, zdjęć i rycin. Na każdej zaś stronie jest zamieszczony jeden z najważniejszych symboli harcerskich: krzyż lub lilijka harcerska. Są jednak w tej publikacji drobne uchybienia. Po pierwsze, wątpliwości budzi chronologia ostatniego rozdziału: lata 1944-1981. Dlaczego finałem tej części jest rok 1981, skoro Autor w tekście znacznie wybiega poza ten rok i snuje narrację aż do 1990 r.? Może zatem data w tytule rozdziału jest zwykłym „,chochlikiem drukarskim”? Jak jednak wytłumaczyć brak bibliografii na końcu książki? Śliwerski co prawda skrupulatnie podaje literaturę w przypisach, jednak jej sumaryczne zestawienie w postaci bibliografii znacznie ułatwiłoby lekturę książki.

Niemniej prezentowana publikacja pozostaje warta lektury i należy odczuwać żal, że tego typu dzieła powstają jedynie przy okazji wielkich obchodów rocznicowych.

Edyta Głowacka Sobiech

\section{Dorota Żołądź-Strzelczyk, Justyna Gulczyńska (red.), 180 lat Szkoly im. Dábrówki w Poznaniu (1830-2010), Wydawnictwo „Rys", Poznań 2010, ss. 311}

Wiosną 2010 r., nakładem Wydawnictwa „, Rys” w Poznaniu ukazała się cenna praca zbiorowa 180 lat Szkoty im. Dąbrówki w Poznaniu (1830-2010), pod redakcją Doroty Żołądź-Strzelczyk i Justyny Gulczyńskiej oraz pod patronatem honorowym Marszałka 